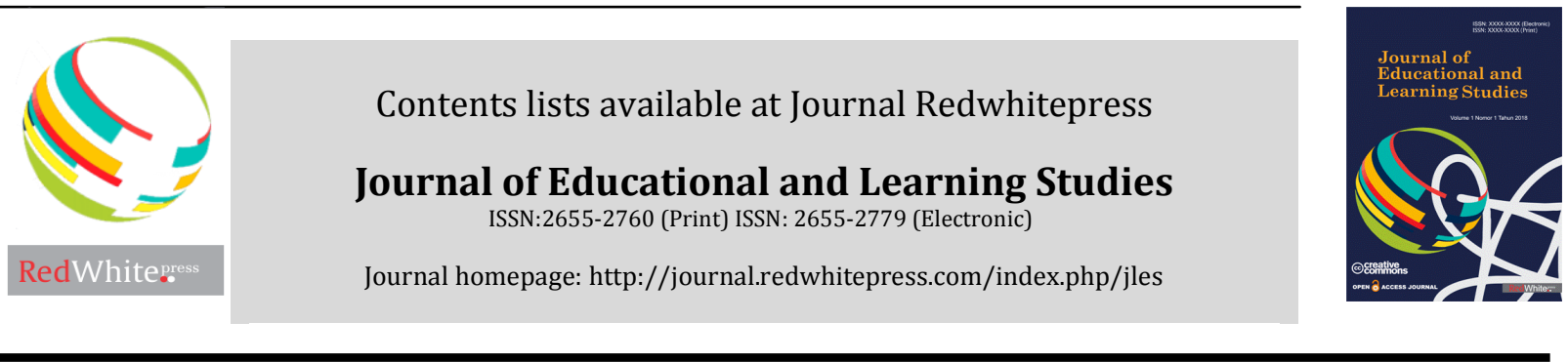

\title{
Vocational high school culture
}

\author{
Rifma $^{1}$, Rusdinal ${ }^{2}$, Ranti Meizatri ${ }^{3}$
}

${ }^{123}$ Universitas Negeri Padang

\section{Article Info}

\section{Article history:}

Received Dec 12th, 2018

Revised Dec 20th, 2018

Accepted Dec 26th, 2018

\section{Keyword:}

School Culture

Vocational High School

\begin{abstract}
School culture becomes one of the determinants formed of students work culture. The lack of attention of school culture has an adverse effect on the character building of students to the low productivity and effectiveness of the school. The aim of the research was to obtain data and information about school culture development in vocational high school. The research employed qualitative research. This research was done in Vocational High School (SMK) Negeri 9 Padang which is one of the favorite vocational high school with all accredited skills program A. Subjects in this research were principal, head majors, teachers, employees, and pupils. Data in this research was collected by using observation, interview, and documentation study. Data were analyzed through three stages: data reduction, data presentation, and conclusion. The results of this study describe the culture of SMK Negeri 9 Padang seen from: (1) behavior; (2) norms; (3) dominant values; (4) philosophy; (5) rules; (6) school climate. The culture has been developing are hospitality culture and work above standard.
\end{abstract}

(C) 2018 The Authors. Published by Redwhitepress.

This is an open access article under the CC BY-NC-SA license

(https://creativecommons.org/licenses/by-nc-sa/4.0/

\section{Corresponding Author:}

Rifma,

Universitas Negeri Padang

Email: rifmar34@gmail.com

\section{Introduction}

Vocational High School plays an important role in preparing generation to compete in various sectors of the economy. Vocational education or vocation that is oriented in the preparation of skilled manpower is expected to become the driving force of local and even national economic strengthening. Vocational High School expected to create a workforce that controls the work competence in accordance with the field, the ability to adapt, and high competitiveness. But in general the problem faced that is not all SMK are able to answer the problem of labor requirements that meet the qualifications required by the world of work. Quantity of vocational graduates who are not absorbed in the business world and the industrial world is quite high. Data from the Central Bureau of Statistics (BPS) in the last 5 years (2010 up to 2015$)$ the level of high school graduates $(90.74 \%)$ is higher than the vocational graduates $(89.19 \%)$. (BPS, Sakernas 2000, 2005, 2010.2015 The average of February and August or November).

Vocational High School has not able to create a replica of the industry in school. Students are accustomed to casual hours of study and work, while in the industry they have to work hard with an hourly average of 40 hours per week. Teachers and students are lack of understanding of Market, Insight 
Quality, Excellence, and Competition. In practice, students are left to work in the wrong way and mistakes are accepted and forgiven as a reasonableness. The quality of the work is left as it is without quality standards. Therefore SMK graduates have less concern and relevance to quality, because schools do not teach the risks of losses for failures, whereas industry failure is a loss that must be borne by workers. Basic training on vocational competencies is not taught in a fundamental way. Practical activities do not follow the principle of due diligence. Students are allowed to work without a clear Standard Operational Procedures (SOPs), whereas the technical quality and work productivity is determined by the correct way of working. Teacher guidance and supervision functions tend to be weak. Teachers let students use equipment not in accordance with the function and place. Furthermore, students are less concerned with work safety and tend to not be responsible for errors of work done.

School culture becomes one of the determinants formed of students work culture. The lack of attention of school culture has an adverse effect on the character building of students to the low productivity and effectiveness of the school. Posnick \& Goodwin in Abdi (2008) state "school culture has an impact on the accomplishment and behavior of students, as well as the motivation, productivity and job satisfaction of teachers. The cultural substance will provide support and identity to the school and will form a framework for learning activities. A positive school culture can create a culture of quality, such as a culture that always supports excellence, a culture of discipline, a culture of togetherness, and other cultures that are oriented towards the quality of education. This is also supported by the results of research conducted by Ali, etc (2016) which states "the highest level of school culture will help achieve the effectiveness of schools at the highest level".

Luneburg \& Ornstain (2000: 60) mention "The culture of an organizational is all the beliefs, feelings, behaviors, and symbols that are characteristic of an organization. More specifically, organization culture is defined as share philosophies, ideologies, beliefs, feelings, assumptions, expectations, attitudes, norms, and values". The elements of school culture are grouped into two categories, namely the visible element and the invisible element. Invisible elements can be manifested conceptually/verbally as well as visual material. Verbal invisible elements include: (1) vision, mission, goals and objectives; (2) curriculum; (3) communication language; (4) school narrative; (5) narrative figures; (6) organizational structure; (7) rituals; (8) ceremonies; (9) teaching and learning procedures; (10) regulation, reward system, and punishment; (11) social psychology services; (12) patterns of school interaction with parents. Visible elements of the visual/material include; (1) facilities and equipment; (2) artifacts and mementos; And (3) uniforms' clothing (Sastrapratedja in Ahyar, 2009).

This study examines deeper on the school culture in SMK Negeri 9 Padang which is the favorite SMK with A accreditation in each of its expertise programs as well as appointed to be one of ten SMK referrals in Indonesia. The results of this study is expected to be used as a reference for the head in an effort to develop vocational high school culture.

\section{Method}

This research was done by employing qualitative approach. Data collection techniques are observation, interview, and documentation study. The informants chosen in this study are the related elements that are able to provide the necessary data and information related to vocational high school culture. Selection of informants was done by using snowball technique (Snowball sampling). For the purposes of this research, the authors set informants of the following elements: principals, heads major, teachers, students, and staffs. Data analysis in this research follow the stages of qualitative descriptive analysis technique used the steps proposed by Miles and Huberman (1992), namely (1) data collection, (2) data reduction, (3) data presentation, and (4) conclusion drawing. To ensure the validity of the data: (1) repeated observations of school activities conducted by both programmable and spontaneous school children and (2) triangulation to ensure that the data collected is consistent with the facts on the ground.

\section{Results and Discussion}

The school cultures found in this study are: (1) behavior, (2) norms, (3) dominant values, (4) philosophy, (5) rules, and (6) school climate. Each of these is described as follows:

\section{Behaviors}

Behavior remains a common reaction that school makers show about environmental stimuli. This behavior can be observed from the language and terms use, how to act and behave. Researchers looked at the behaviors displayed by employees, teachers, and students in two segments 
First, the observed behavior during the learning activities of the theory shows that the learning process has not been effective. Most students appear to be less interested in following lessons, especially on adaptive and normative subjects. This is evidenced by the large number of students, especially men outside of the learning process, the classroom atmosphere is often uncontrollable because many students fuss about things outside of learning, and a few appear to be stealthily opening mobile phones (observation on 20 April 2017). While it is often seen that teachers (T-1) are less able to control the activities of students who are not associated with learning activities at that time so tends to ignore it. Observations of students' learning activities in the classroom on April 27, 2017, found a situation that is not much different from the observations of April 20, 2017. The situation of the five classes in a noisy state is uncontrollable like the preliminary observations, while the other three classes remain conducive even though visible students often go in and out.

Second, Student behaviors when they are practice and work in the Production Unit. The author observes the implementation of cooking practice Catering Department class X and XI on April 20, 2017. The kitchen situation of class $\mathrm{X}$ is very noisy. Had conditioned his teacher but noisy again. At that time there were two groups that did not carry the full range of practice materials, so had to go buy the material first out. Teachers are often out of the kitchen to find a complete cooking or just out. This leads to uncontrolled student practice activity. It appears that some groups are still confused about what to do, so they often walk to ask other groups that cause the kitchen situation even more fuss. Initially SOPs have been implemented such as washing equipment and materials before use. But during the cooking process, the kitchen situation is getting out of hand. All the equipment was messy, the kitchen floor was muddy because water spills everywhere, and cooking materials scattered about.

Furthermore on May 13, the researcher returned to class XI continental food processing practice class. The observations show the same kitchen situation as the previous practice. This makes the kitchen becomes more chaotic because students have a chance to play while preparing materials and cooking utensils. In addition to the cooking rhythm, XI class is more regular than class X. No more basic questions related to basic techniques of preparing and processing food that is often the cause of the commotion in class X. The next day on 27 April, 2017 researchers got a chance to observe the kitchen pastry. At that time, the department of pastry got a project of order consumption meeting one government agency. Teacher involves seven students who are considered to have good competence from class XI.Teacher stated that the involved students were replaced whenever the school got the project. So almost every student pastry majors get real experience working in Unit Production. Differ another previous of practices class, the pastry kitchen looks very controlled. There is even no talk between students, each focusing on the assigned work field. Two pastry teachers directly coordinate the kitchen activities neatly.

We can concluded that the behavior of students SMK Negeri 9 observed not reflect the values developed in schools, especially during the process of learning theory and practice in school. But what is interesting is that when students engage in entrepreneurial activities in the school production unit, they look very orderly implement SOP. This gap occurs because the learning system in practice that gives less moral and material responsibility to students for the work they do. On the other hand the behaviors that students display when the practice becomes a characteristic of the stage of its development. At that age they need social interaction with others.

\section{Norms}

As a tourism vocational high school, the students' performance becomes a standardized part of the school and is legally binding as a school rule. Despite the nature of the school rules, the standard of performance of students of SMK Negeri 9 developed into the norms held by students including teachers and school employees. Norms in appearance have been internalized in the students. If there are students who violate the standard of school appearance it will immediately look the difference from other students. In relation to that the principal stated "schools use a special uniform, students wear long-sleeved shirts and leather heel shoes are black. Students who are not wearing uniforms are listed as a violation, and they are out of the norm. More details have been described in the discipline of students "(interview on April 26, 2017).

\section{Dominant Values}

SMK Negeri 9 has the dominant values that are expected and supported always to always be practiced by all the citizens of the school. These dominant values are guest glorifying (hospitality) and work above the standard. The guest glorifying is a dominant value that determines the characteristic of SMK Negeri 9 as a tourism SMK and work above the standards is the work characteristic of a true entrepreneur. Interview with the principal on 26 April 2017 mentions: 
The dominant values that the school develops as well as the characteristics of SMK Negeri 9 are: First, who has been entrusted in this school, "guest glorifying". Glorifying the guests is not always a cost-oriented, material situation. Can greet people, deliver people to their destination, serve or speed up people's affairs. Second, "doing work above the standard". If we work the standard is normal, if you go to school at 7, people come at 7 it standard. If he comes at 6:30 it's above standard. If people work 8 hours a day and then come home in the afternoon, that's normal. If people have gone home at 4 or 5 o'clock it is above the standard. If people teach 45 minutes, that's standard. If he serves until the child understands and understands it is above the standard. That's what culture is here $(\mathrm{Pc})$.

Dominant values are highly regarded in work in SMK Negeri 9 are to glorify the guest (hospitality) and work above the standards. When students work in a production unit there is an awareness of greater responsibility because the work they do is related to customer satisfaction. In this case students already have an awareness of "economic effects" on his behavior in work. While working in a production unit they are trying to actualize themselves by working professionally. School activities consistently lasted approximately until $5 \mathrm{pm}$. This is one indication that the headmaster "works above the standards". From the results of the observation shows that after the learning hours are completed, the teachers are still active in their respective projects. Hotel teachers are gathered in their room on the 2nd floor of the school building, while culinary teachers gather in their room on the 1st floor. Teachers are still work, some are preparing learning tools, checking students' assignments, discussions, or simply talking-talk. Occasional kitchen, café, laundry and hotel activities are still visible when additional hours of practice, catering orders, and hotel guests are busy.

\section{Philosophy}

Philosophy is the values of belief or ideology that is believed and practiced by all citizens of the school. The philosophy of SMK Negeri 9 is contained in the phrase "The Real Entrepreneur School". In an interview dated April 27, 2017 the principal asked "The Real Entrepreneur School has the meaning that students are taught really entrepreneurship. Students do the real work. We have a laundry, hajj catering, and pastry. Students do not deliberate in learning."

The philosophy of SMK Negeri 9 Padang is The Real Entrepreneur School. It has been proven through entrepreneurial activities in schools that are part of the teaching factory program. In developing entrepreneurial culture in vocational schools there are three important factors that need attention. First, an open mindset that entrepreneurship should be able to look out. So people who want to have an entrepreneurial spirit to open minded. However, open thinking is not enough, must be equipped with flexibility skill, which has the ability to think flexibly by developing entrepreneur approach. Second, it would be more perfect if the principals and teachers, in preparing students to have entrepreneurship skills, have technical skills, technical skills. Third, entrepreneurs interact with the wider community and the world of different disciplines. For entrepreneurship is not just for yourself (Noah: 2009).

\section{Rules}

The regulation of SMK Negeri 9 Padang is contained in the document of discipline as the regulation/stipulation of school in controlling the behavior of students. The rules of discipline contain 10 articles consisting of general parts, personal activities, students' rights, uniforms, additional duties, prohibitions, sanctions and closings. To enforce this regulation, SMK Negeri 9 establishes the picket teacher, disciplinary commission, homeroom teacher, student representative, and headmaster to be part of the implementation and supervision mechanism, and to decide on the act of fostering and sanctioning the violation. Sanctions for violations of school rules or rules are grouped into five categories: (a) specific disciplinary measures of self-discipline, (b) special attenuation sanction of attendance in learning, (c) sanction of special rules of students in the improvement and enrichment, (d) sanction of special rules of students in additional duties (cafeteria, hotel picket, café, catering, daily worker, and students in the race), (e) special sanction for students who do not perform flag, spiritually and ceremonies, f) sanctions to all local members responsible for activities in the form of equipment activity fines, for example: ceremonial completeness, Qur'an, Dictionary.

\section{School Climate}

The school climate is an atmosphere that psychologically can be perceived as a result of interaction among school members. Based on the observations during the study period, it can be concluded that the dominant climate built in SMK Negeri 9 Padang is the climate of cooperation and family climate. This is 
in line with the statement of the principal that mentions one of the basic values emphasized in SMK Negeri 9 is cooperation. Cooperation is one of the dominant school climates that can be felt in almost every school such as during practice, work in production unit (UP), in department office, and in other work units. Climate cooperation has been awakened from the beginning because everyone is accustomed to working in a team. Therefore, cooperation has become part of work character that has developed in SMK Negeri 9 Padang.

Furthermore, kinship is also a dominant climate that can be felt in SMK Negeri 9 Padang. Familiarity between teachers and students become easy to find in school. Informal communications often occur between teachers and students or students and school staff outside of school hours. BK space and student representatives are seen often visited students though only to just say hello or tell a story with teachers. From the observation of school interaction almost every teacher recognized the students with the class. This proves during the interaction of learning has established a strong relationship between teachers and students. School environments in which a sense of togetherness among teachers is high, adequate facilities support, high academic targets, and school integrity stability as an institution support the achievement of better academic achievement (Hoy \& Hannum in Daryanto: 2015).

On the other hand, the familial atmosphere among teachers is also felt in their respective majors. The results of interviews with head major of catering service on 26 April, 2017 states:

If not a reason to boil the catering service major teachers who come home after school hours. We gathered to discuss materials, discuss child behavior, calculate the cost of the practice, complete the child's task corrections, or just chatting. We also often cook together for example if there is excess material practice. We make food and distribute it to other friends who are still at school. It was so much fun from going home quickly. Occasionally we also play out, eat, watching, singing. All culinary teachers are invited, including honor teachers and OT teachers we invite all (HM-CS).

The same is true in the hospitality department. Hotel teachers often seem to gather in their majors or at Edotel (Educational Hotel in school). Similarly, culinary teacher teachers' activity teachers discuss the behavior of students, evaluate the subject matter and tasks of the students or simply observe the work of the students who picket and help serve guests in Edotel. The familial climate also confirmed by the chairman of the hospitality department. Interview on 29 April, 2017, the head of the hospitality department explains how interaction of teachers among the following orders:

We are stay in intimate, no clustering. It's just because the different work units the intensity of the meeting becomes less. If you see culinary teachers and hospitality rarely together in school it is normal. Catering service teachers busy in the kitchen, we are busy at the hotel. But outside our familiar work, all the teachers here know each other well including honor teachers and OT teachers. We have an social gathering held twice a month, recitation every Friday morning, teacher meetings, and other meetings both formal and non formal we mixed together, no more catering service teachers or hotel management teachers, we are teacher at SMK Negeri 9 (HM-MH)

On May 5, 2017 researchers observed the In House Training (IHT) meeting of teachers of SMK Negeri 9, when it was true that the chairman of the department of hospitality stated that teacher look familiar mixed when IHT implemented. There was no seating grouping, nor the conversation between the teachers, all blurry.

\section{Conclusions}

School culture is a typical school characteristic that can be identified through the values, attitudes, habits displayed and actions shown by all school personnel that form a special activity of the school system. Characteristics of school culture cant separated from the existence of the school itself as an educational organization, which has the role and function to develop, preserve and pass on various cultural values to students. The results showed that the behavior of students of SMK Negeri 9 that was observed did not reflect the values developed in schools, especially during the process of learning theory and practice in schools. But what is interesting is when students engage in entrepreneurial activities in the school's production unit, they look very orderly implement SOP. Dominant values are highly regarded in work is to glorify the guest (hospitality) and work above the standards. When students work in a production unit there is an awareness of greater responsibility because the work they do is related to 
customer satisfaction. Philosophy of SMK Negeri 9 Padang is The Real Entrepreneur School which has been proven through entrepreneurship activities in schools that become part of the teaching factory program. Cooperation and kinship is a dominant climate that can almost be felt in every part and activity done in school for example when practicing, working in production unit, in department office, and in other work units. Climate cooperation has been awakened from the beginning because everyone is accustomed to working in a team. Therefore, cooperation has become part of the working character that has grown.

\section{References}

Abdi, Rahmani. (2008). AL- Risalah Jurnal Ilmiah Keagamaan dan Kemasyarakatan. http://web.stairakhaamuntai.ac.alrisalah_vol.4_no.1_th.pdf. Diakses tanggal 16 Januari 2017

Ahyar. (2009). Jurnal ilmiah "kreatif" Sekolah Sehat Sebuah Tinjauan Akademis". http://jurnal.pdii.lipi.go.id/admin/jurnal/61091726.pdf. diakses tanggal 10 Januari 2017.

Ali, dkk. (2016). School Culture and School Effectiveness: Secondary Schools in Pakistan (Malaysian Online Journal of Education Management). Vol 4, Issue 4. Halaman 50-65.

Daryanto. (2015). Pengelolaan Budaya dan Iklim Sekolah. Yogyakarta: Gava Media.

Diayuningsih, Irma \& Totok Suyanto. (2014). Pola Pengembangan Nilai-Nilai Karakter Melalui Kultur Sekolah di SMK Wachid Hasyim 2 Taman Sidoarjo. Jurnal Kajian Moral dan Kewarganegaraan. Nomor 2, Vol 1. Hal 31-45.

Instruksi Presiden Nomor 19 tahun 2016 tentang Revitaslisasi Pendidikan Vokasi.

Luneburg, Fred C \& Allan C. Ornstain. (2000). Educational Administration: Concept and practice. USA: Thomson Learning.

Miles, Matthew B. and A. Michael Huberman. (1992). Qualitative data Analysis. Sage Publication, Inc.

Permendiknas Nomor 19 Tahun 2007 tentang Standar Pengelolaan Pendidikan oleh Satuan Pendidikan Dasar dan Menengah.

Undang-Undang Nomor 20 Tahun 2003 tentang Sistem Pendidikan Nasional. 